\title{
Women Investors Recital At Rajapalayam City - A Study
}

\author{
Dr.C.Jothi Baskara Mohan, Mr.P.R.Ramji. \\ M.B.A.,M.Sc(Pcy).,M.Phil.,Ph.D.,Associate Professor, Department of Business Administration, \\ Thiagarajar College, (Autonomous),Madurai- 625 009. Tamilnadu.INDIA. \\ M.H.R.D., Assistant Professor, Department of Business Administration, Rajapalayam Rajus' \\ College,Rajapalayam-626 117.Tamilnadu.INDIA.
}

\begin{abstract}
This paper divulge with women investor behavior (Recital) of investment and the various investment available for the purpose of women, especially in Rajapalayam. There is a detailed discussion on women source of awareness and knowledge of investment. Also, how and why a woman has become a means of investment is briefly touched. Finally, why a woman should make an investment and should not make such an investment is also dealt with. An advisory note about women investors is added in the end.

Keywords: Women, Investment, Awareness, Knowledge.
\end{abstract}

\section{Introduction}

Savings form an important part of economy of any nation. Moreover, a woman plays a vital role at this state of affairs in our nation. With the savings invested in various options available to the women, money acts as the driver for growth of our country. The first step was acquiring the knowledge about investment that would help women breach the barricades of the male-dominated budgets.

\subsection{INVESTMENT}

History

The Code of Hammurabi 1700 B.C. provided a legal framework for investment establishing a means for the pledge of collateral by codifying debtor and creditor rights in regard to pledged land. Punishments for breaking financial obligations were not as severe as those for crimes involving injury or death.

In the early 1900s purchasers of stocks, bonds, and other securities were described in media, academia, and commerce as speculators. By the 1950s the term investment had been co-opted by financial brokers and their advertising agencies to promote speculation. By the late 1900s the terms speculation and speculator were somewhat down played by the media, likely due to turmoil.

\section{Meaning}

1. Money committed or property acquired for future income.

2. Two main classes of investment are

a. Fixed income investment such as bonds, fixed deposits, preference shares, and

b. Variable income investment such as business ownership (equities), or property ownership.

3. Expenditure on education and health is recognized as an investment in human capital, and research and development in intellectual capital.

4. Return on investment (ROI) is a key measure of an organization's performance.

5. In economics, investment means creation of capital or goods capable of producing other goods or services.

\subsection{PROBLEM STATEMENT}

The statement of problem under this study is to analyze the attitude of women investors in various investments and their preference. This problem tries to indentify the women investors insight and their ability why investing.

\subsection{OBJECTIVES OF THE STUDY}

1. To know women awareness towards investment.

2. To study investment knowledge of women.

3. To analyze the investment pattern of women investors with regards to various Age group, Occupation, Income, investment goals \& Objectives of Investment

\subsection{SCOPE OF THE STUDY}

The survey gathered data from the women gender unit. Data gathered were especially relating to women investors. Related information such as demographic and economic characteristics of the population and 
characteristics were also included. The survey involved the interview of a sample of 50 women spread across the rajapalayam town.

\subsection{REVIEW OF LITERATURE}

A review of literature was added to this study by referring to different journal and studies conducted by different individuals to show relevance to the study.

Armstrong (1979) revealed that higher level employees care more for self actualizing valves like advancement, recognition and independence whereas lower level employees care more for salary, fringe benefits and happiness.

Vanita (1988) according to men enjoy superior status in the households and they only take most of the important decision concerning family matters. Women's participation in gainful employment is bound to bring changes in their position in the family. Working women jointly or independently manage the family budget.

\subsection{RESEARCH METHODOLOGY}

Research methodology is a way to systematically solve the research problem. It may be understood as a science of studying how research is done scientifically. In it we study the various steps that are generally adopted by a researcher in studying his research problem along with the logic behind them. It is necessary for the researcher to know not only the research methods/techniques but also the methodology.

\section{$>$ Research Design}

Initially, a rough draft will be prepared keeping in mind the objectives of the research. The final questionnaire will be arrived at only after certain important changes are incorporated. The study is intended to find women investor towards various investments.

$>$ Type of Research

This is descriptive research where survey method is adopted to collect primary data from the women investors and secondary for analysis. Descriptive study is a fact-finding investigation with adequate interpretation. It is the simplest type of research and is more specific. Mainly designed to gather descriptive information and provides information for formulating more sophisticated studies.

\section{$>$ Sample Method}

The sampling method followed in this study is convenience sample method. A convenience sample is a matter of taking what you can get. It is an accidental sample. Although selection may be unguided, it probably is not random, using the correct definition of everyone in the population having an equal chance of being selected. Volunteers would constitute a convenience sample.

$>$ Sample Unit

The respondent who will be asked to fill out the questionnaires are the sample unit. These comprises of Women in Households, Women Employees, Women Entrepreneur and others.

$>$ Sample Size

The population being large the survey was carried among 50 respondents, most of them are household.

$>$ Data Collection

The data is collected by means of both primary and secondary data collection method.

- Primary: The Questionnaire schedule was prepared and the primary data was collected through survey method. The time period for the collection of data is about 3 weeks.

- Secondary: Data used in a secondary data analysis may have been collected in a previous research, Books, journals, Website, but may also include data collected outside of research. The time period for the collection of data is about 4 weeks.

$>$ Tools for Analysis

A simple percentage too
$>$ Technical Tools for the Survey

The analysis of data collection is completed and presented systematically with the use of MS. Word and Excel. It consists of Charts, Tables etc.

\subsection{LIMITATION OF THE STUDY}

- The investment attitude analysis has been limited to only 50 women investors

- It is conducted in Rajapalayam city

- This study in conducted to analyze the behavioral pattern not all those factors that really matter while investing.

- Besides the study has the limitation of time, place and resource. 
1.9 DATA ANALYSIS

Table 1.1 AGE CLASSIFICATION

\begin{tabular}{|l|c|c|}
\hline Age & $\begin{array}{l}\text { No. of } \\
\text { Respondents }\end{array}$ & Percentage \\
\hline $20-30$ & 23 & 46.0 \\
\hline $31-40$ & 13 & 26.0 \\
\hline $41-50$ & 10 & 20.0 \\
\hline Above 60 & 04 & 8.0 \\
\hline Total & $\mathbf{5 0}$ & $\mathbf{1 0 0 . 0}$ \\
\hline
\end{tabular}

Source: Primary Data

\section{Table 1.2 OCCUPATIONS}

\begin{tabular}{|l|c|c|}
\hline Occupation & $\begin{array}{l}\text { No. of } \\
\text { Respondents }\end{array}$ & Percentage \\
\hline High school & 10 & 20.0 \\
\hline U G & 20 & 40.0 \\
\hline P G & 16 & 32.0 \\
\hline Professionals & 10 & 20.0 \\
\hline others & 04 & 8.0 \\
\hline Total & $\mathbf{5 0}$ & $\mathbf{1 0 0 . 0}$ \\
\hline
\end{tabular}

Source: Primary Data

Table 1.3 FAMILY INCOMES / MONTH

\begin{tabular}{|l|c|c|}
\hline Income & $\begin{array}{l}\text { No. of } \\
\text { Respondents }\end{array}$ & Percentage \\
\hline Below 20000 & 24 & 48.0 \\
\hline $20000-40000$ & 12 & 24.0 \\
\hline $40000-60000$ & 10 & 20.0 \\
\hline Above 60000 & 04 & 8.0 \\
\hline Total & $\mathbf{5 0}$ & $\mathbf{1 0 0 . 0}$ \\
\hline
\end{tabular}

Source: Primary Data

Table 1.4 SOURCE OF AWARENESS

\begin{tabular}{|l|c|c|}
\hline Awareness & No. of Respondents & Percentage \\
\hline Family & 10 & 20.0 \\
\hline Friends\& Relatives & 20 & 40.0 \\
\hline Brokers /Agents & 16 & 32.0 \\
\hline Media & 04 & 8.0 \\
\hline Total & $\mathbf{5 0}$ & $\mathbf{1 0 0 . 0}$ \\
\hline
\end{tabular}

Source: Primary Data

Table 1.5 INVESTMENT KNOWLEDGE

\begin{tabular}{|l|c|c|}
\hline Investment & No.of Respondents & Percentage \\
\hline Capital market & 02 & 4.0 \\
\hline Banking & 05 & 10.0 \\
\hline Jewels & 20 & 40.0 \\
\hline Insurance & 12 & 24.0 \\
\hline Post Office & 01 & 2.0 \\
\hline Real Estate & 10 & 20.0 \\
\hline Total & $\mathbf{5 0}$ & $\mathbf{1 0 0 . 0}$ \\
\hline
\end{tabular}

Source: Primary Data 
Table 1.6 INVESTMENTS PREFERRED

\begin{tabular}{|l|c|c|}
\hline \multicolumn{1}{|c|}{ Preference } & No.of Respondents & Percentage \\
\hline Capital market & 02 & 4.0 \\
\hline Banking & 10 & 20.0 \\
\hline Jewels & 18 & 36.0 \\
\hline Insurance & 10 & 20.0 \\
\hline Post Office & 02 & 4.0 \\
\hline Real Estate & 08 & 16.0 \\
\hline Total & $\mathbf{5 0}$ & $\mathbf{1 0 0 . 0}$ \\
\hline
\end{tabular}

Source: Primary Data

Table 1.7 ATTAINMENTS OF INVESTMENT GOALS

\begin{tabular}{|l|c|c|}
\hline Amount Invested & No.of Respondents & Percentage \\
\hline Below 5 years & 18 & 36.0 \\
\hline $6-10$ years & 16 & 32.0 \\
\hline $11-15$ years & 10 & 20.0 \\
\hline Above 15 years & 06 & 12.0 \\
\hline Total & $\mathbf{5 0}$ & $\mathbf{1 0 0 . 0}$ \\
\hline
\end{tabular}

Source: Primary Data

Table 1.8 AMOUNTS INVESTED PER MONTH

\begin{tabular}{|l|c|c|}
\hline Amount Invested & No.of Respondents & Percentage \\
\hline Below 2000 & 10 & 20.0 \\
\hline $2001-4000$ & 35 & 70.0 \\
\hline $4001-6000$ & 6 & 12.0 \\
\hline Above 6000 & 1 & 2.0 \\
\hline Total & $\mathbf{5 0}$ & $\mathbf{1 0 0 . 0}$ \\
\hline
\end{tabular}

Source: Primary Data

Table 1.9 OBJECTIVES OF INVESTMENT

\begin{tabular}{|l|c|c|c|c|c|c|}
\hline Objectives & $\begin{array}{l}\text { House } \\
\text { Purchase }\end{array}$ & Education & Retirement & $\begin{array}{l}\text { Child } \\
\text { Marriage }\end{array}$ & Others & $\begin{array}{l}\text { Percent } \\
\text { age }\end{array}$ \\
\hline $\begin{array}{l}\text { Strongly } \\
\text { Agree }\end{array}$ & 31.0 & 33.0 & 4.0 & 32.0 & - & $\mathbf{1 0 0 . 0}$ \\
\hline Agree & 30.0 & 30.0 & 2.0 & 30.0 & 8.0 & $\mathbf{1 0 0 . 0}$ \\
\hline Fair & 10.0 & 10.0 & 15.0 & 26.0 & 49.0 & $\mathbf{1 0 0 . 0}$ \\
\hline Disagree & 10.0 & 17.0 & 43.0 & 10.0 & 20.0 & $\mathbf{1 0 0 . 0}$ \\
\hline $\begin{array}{l}\text { Strongly } \\
\text { Disagree }\end{array}$ & 19.0 & 10.0 & 36.0 & 2.0 & 33.0 & $\mathbf{1 0 0 . 0}$ \\
\hline
\end{tabular}

Source: Primary Data

\subsection{SUMMARY OF FINDINGS}

1) Most of the respondents (46\%) are of the age group 20-30.

2) Most of the respondents (40\%) are graduates.

3) Most of the respondents (26\%) are Private employees.

4) Most of the respondents (76\%) are married women.

5) Most of the respondents are having an Income level of Below $20000(48 \%), 24 \%$ are of 20000-40000 and $20 \%$ of $40000-60000$.

6) $92 \%$ of respondents are aware of Investment and remaining $8 \%$ are unaware.

7) $40 \%$ are influenced by friends and relatives and $20 \%$ are by Family members.

8) Most of the respondents $40 \%$ are very good understood towards investment in Jewels.

9) $24 \%$ of the respondents are very good understood towards investment in Insurance.

10) $20 \%$ of the respondents are very good understood towards investment in Land.

11) $10 \%$ of the respondents are very good understood towards investment in Banking.

12) Only $4 \%$ of the respondents are very good understood towards investment in Capital Market. 
13) Only $2 \%$ of the respondents are very good understood towards investment in Post Office.

14) $36 \%$ of respondents preferred Investment in jewels, equal respondents of $20 \%$ each preferred investment in both banking and insurance.

15) $36 \%$ of respondents are in the time period of below 5 years to attain investment goals and $32 \%$ are in the time period of 6-10 years.

16) $70 \%$ are about $2001-4000$ of income per month on investment, $20 \%$ are below $2000,12 \%$ are invested about 4001-6000 and only $2 \%$ are above 6000 .

17) $72 \%$ of respondents preferred cash mode for payment.

18) $40 \%$ of respondents invested for child benefits, $30 \%$ for savings, $20 \%$ for Regular Income and $10 \%$ for Safety towards reason for investment.

19) Majority of the respondents $32 \%$ are strongly agree on child marriage towards the objective of investment.

20) Majority of the respondents $33 \%$ are strongly agree on Education towards the objective of investment.

21) Majority of the respondents $31 \%$ are strongly agree on house purchase towards the objective of investment.

22) Majority of the respondents $4 \%$ are strongly agree on retirement towards the objective of investment.

\subsection{SUGGESTIONS}

1) Women have invested a very less percentage in capital market and post office of their income as they don't have a thorough knowledge.

2) A majority of women have not planned for their finance as opportunities have come.

3) Most of the women have a basic understanding about investing which is good trend to encourage more participation in investment.

4) They invested in bank, jewels, Insurance which has low risk.

\section{Conclusion}

Women Investors Attitude in 2012, Women represent a significant client opportunity for investment professionals, both because of their expanding economic power and because of their prevalent dissatisfaction with the service they are receiving now in Rajapalayam city. The present study has important implications for investment as it has come out with certain interesting facts of women investors. The women investors prefer to invest in financial product which give risk free returns. This confirms that women investors even if they are high income, well educated, salaried are traditional investor prefer to play safe savings and low risk.

\section{Book Reference}

\section{References}

[1] Abbott .L. Ferris, Indicators of Trends in the Social Status of American Women (New York: Russell Sage, 1971).

[2] Robert. O. Blood and Robert L. Hamblin, "The Effect of the Wife's Employment on Family Power Structure", Social Forces, 36 (may 1958), pp. 347-352.

\section{E- Reference}

[3] http://www.scribd.com/doc/60175369/Investment-Habits-of-Working-Women

[4] http://www.slideshare.net/manovikas/31128326/ananalysisofinvestorsbehaviouronvariousinvestmentavenuesinindia 